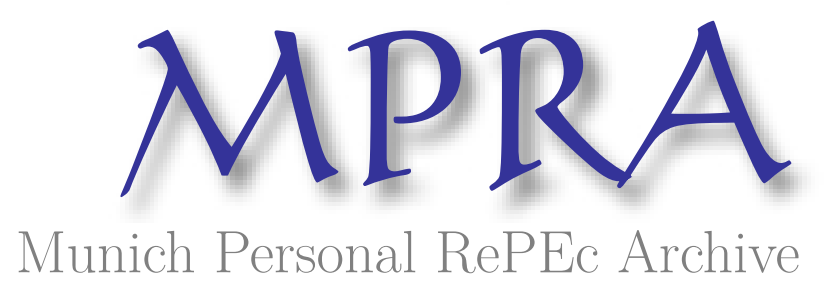

\title{
Transportation Infrastructure and Economic Growth in a Dissolving Country: (Ir)relevance of Railroads in the Ottoman Empire
}

Hanedar, Avni Önder

Dokuz Eylül University, Sakarya University

9 September 2013

Online at https://mpra.ub. uni-muenchen.de/77974/

MPRA Paper No. 77974, posted 11 Apr 2017 07:29 UTC 


\title{
Transportation infrastructure and economic growth in a dissolving country: (Ir)relevance of railroads in the Ottoman Empire
}

\author{
Avni Önder Hanedar* \\ Dokuz Eylül University, İzmir, Turkey \\ Sakarya University, Faculty of Political Sciences, Sakarya-Turkey
}

Acknowledgement: I should like to thank Sedef Akgüngör, Mehmet Yavuz Erler, Nurullah Gür, Rowena Gray, Timothy Hatton, Patrick J. Nolen, Joao M. C. Santos Silva, George Symeonidis, Şevket Pamuk, and Murat Özyüksel for help and suggestions. I am grateful for comments of participants in the Research Strategy Seminar (RSS) at the University of Essex.

\begin{abstract}
In the literature, there are few studies on the impacts of the railroad construction in the Middle Eastern countries as well mixed findings. Using the data on the population of judicial districts in the Ottoman Empire between 1893 and 1914, we examine the relationship between railroad access and economic growth in local economies. Our empirical results show the size expansion in the affected areas of railroad access. This suggests the presence of positive impact of railroads on economic growth through increasing employment opportunities and fertility rates. To deal with endogeneity problems, we use instrumental variable (IV) strategy. Our 2SLS results also indicate that the causality runs from access to railroads to population growth. The paper contributes to the previous empirical literature by providing evidence for an agricultural society with limited factor mobility due to the lack of transportation infrastructure.

Keywords: Railroads, The Ottoman Empire, Economic growth, Population growth, 2SLS JEL classification numbers: N75, N95, 04
\end{abstract}

\section{Introduction}

Access to railroads is seen as one of the key drivers of long-run economic growth. The positive effect of railroads on trade, productivity, production, and population has been demonstrated for many countries from Germany to India (such as Hornung 2015; Donaldson 2010). This positive effect of access to railroad works mainly through decreasing transportation costs, which provides new markets for goods and creates job opportunities (Wang \& Wu 2015; Jedwab \& Moradi 2016).

In this paper, we examine the impact of access to railroads on economic growth in the Ottoman Empire. Analysing the effect of railroads on Ottoman economy is important for several reasons. First, the historical developments shed light on today's realities (Nunn 2009). Second, although the effects of historical railroads on economic

\footnotetext{
* Corresponding author. Dokuz Eylül University, Faculty of Business, Kaynaklar Yerleşkesi 35160 Buca İzmir-Turkey e-mail: onderhanedar@gmail.com phone: +905393453073
} 
performance in many countries have been investigated several times (such as Fogel (1964), Atack et al. (2011), Caruana-Galizia \& Martí-Henneberg (2013), Donaldson (2014), Hornung (2015), Donaldson \& Hornbeck (2017)), there were not many papers for underdeveloped and the Middle Eastern countries (see Akgungor et al. (2011), Banerjee et al. (2012), Wang \& Wu (2015), Ansar et al. (2016), and Jedwab \& Moradi (2016)). Third, in the Ottoman Empire the main motivation for building railroads was not economic but political, which is firstly econometrically addressed by our paper. The Ottoman state mainly desire to build railroads to exercise political control over the territories by mobilization of troops to fight against rebellions and wars in remote locations. Duranton \& Turner (2007) argues that the political motive for construction does not guarantee that the effect of roads on economic growth is positive and strong. Last, the positive impact of railroads on economic outcomes is not a settled topic, while Fogel (1964), Haines and Margo (2008), Banerjee et al. (2012), and Ansar et al. (2016) evince that railroads were not indispensable for economic growth and agricultural output in the US and China.

Since the early nineteenth century, railroads emerged as a new form of transportation in Europe and US. In 1856, the construction of railroad lines in the Ottoman Empire began. Although many of its parts were isolated, railroad networks grew rapidly until 1914, which connected Rumelia ${ }^{1}$ with its other parts such as Hejaz, Syria, Iraq, and Anatolia. In the historical literature, several researches argue a substantial increase in trade and agricultural production, as places had gained access to railroads. ${ }^{2}$ There is a strand of literature pointing that railroads led to lower production in connected places due to higher imports resulted in the domestic industry being hampered in places where railroad lines were located (Quataert 1996: 814). Another strand of the literature states the absence of economic growth due to railroads. This strand is based on the argument that railroad lines were not adequately connected to one another (Ortayli 2010: 166), ${ }^{3}$ and resultantly the passenger and good traffic was not intense. Another reason for the low level of the traffic is that railroads were not

\footnotetext{
${ }^{1}$ Land of the Ottoman Empire in Europe.

${ }^{2}$ See British Parliamentary Paper (1896: 10), Karkar (1972: 65, 82), Quataert (1977; 1996: 810-814; 2005: 126), Eldem (1994: 94), Gülsoy (1994: 245-246; 2010: 181-182, 270), and Hülagü (2010: 14-45). ${ }^{3}$ All major European powers (i.e., the UK, France, Germany, Russia, Italy, and Austria-Hungary) wanted to build railroads to control places politically and economically (Illich 2007: 91-93; Geyikdağı 2011: 54-55). The construction of the railroads by one power would create a threat to its rivals' economic and political dominance in the respective location. Competition among the major European powers to control the respective location via railroad investments would create conflicts (Ortayli 2010, pp. 165-166).
} 
connected with highways (Eldem 1994: 105). In addition, as foreign firms abused kilometric guarantee system to get more money, they built the railroads in places that railroads were not needed (Schoenberg 1977; Karkar 1972: 111; Issawi 1982: 60; Owen 2002: 196-197). Similarly, the Ottoman state wanted railroads to be built in places of political and military importance that had not high population. Moreover, several railroad lines were located in less populated or economically important places where famines had been often seen (Karkar 1972: 111; Quataert 1977; Schoenberg 1977; Quataert 1996: 789; Erler 2010: 304-312; Gülsoy 2010: 27, 132, Hülagu 2010: 23-25).

In sum, it is an empirical question whether access to railroads affected economic growth or not in the Ottoman Era. In this paper, we use population data for 628 judicial districts (known as kazas) from 32 provinces (known as vilayets) in the Ottoman Empire for the years between 1893 and 1914 to examine whether access to railroads induced economic growth in the Ottoman Empire. In addition to controversial arguments in the historical literature, the railroad construction in the Ottoman Empire provides an ideal case to examine the consequences of railroad construction for an agricultural society in which factor mobility is limited, as its existing road networks were not well developed due to financial difficulties and lack of technological knowledge in building of roads. On the other hand, at the same period many other countries' road networks were rapidly expanding (Schoenberg 1977; Quataert 1996: 804; Gülsoy 2010: 27).

There is no data source with information about economic outcomes at the judicial district level for the Ottoman Empire. We conduct a similar analysis to Hornung (2015) using population data of urban areas to examine local economic growth due to railroads in Prussia. Hornung (2015) finds a positive impact of railroads on population in connected urban areas in Prussia for the period 1840-1871 and argues that railroad access induced economic growth, which was positively related to employment opportunities in connected urban areas during the industrial development. This attracted people to find jobs in the respective areas, as income and the number of factories increased. ${ }^{4}$

\footnotetext{
${ }^{4}$ Our sample consists of population in urban and rural places, while there lack of such definition for the Ottoman Empire. Hornung (2015) argues that urban population growth is a good proxy for economic growth, as human and physical capital was mostly located in these areas. See Table 4 showing that the coefficient estimate for the effect of railroads on population growth in mostly populated areas is not different much from the coefficient estimate obtained from full sample.
} 
Our OLS results indicate a positive relationship between railroad access and population in the affected areas, suggesting an inflow of people due to higher production and job opportunities. But, as the previous literature underlines, the placement of railroad lines is endogenous to economic and demographic outcomes in a region, which could lead to biased OLS estimates for the impact of railroads. To deal the bias, they construct instrumental variables for measures of railroad access (Atack et al. 2010; Banerjee et al. 2009; Donaldson 2010; Atack \& Margo 2011; Kotavaara et al. 2011; Schwartz et al. 2011; Koopmans et al. 2012; Berger \& Enflo 2015; Hornung 2015). Following the previous literature, we also use 2SLS by using historical trade routes as an instrumental variable for access to railroads. Our 2SLS results also demonstrate that access to railroads had positive impact on population growth. This suggests that the railroads were a crucial proxy for economic growth in the historical context.

We extend the previous literature on the impact of railroads by presenting evidence for an understudied region in which the effect of the railroads has been greatly debated by historians. Our paper is different from previous studies on the Ottoman railroads (see Beyzatlar (2010), Kolars \& Malin (1970), and Akgungor et al. (2011, 2012) $)^{5}$ because of using population data at judicial district level, which consisted of many present-day countries. ${ }^{6}$ In addition, our paper is the first to address the placement decisions of the railroad lines in the Ottoman Empire and various measurement errors in the historical data using an instrumental variable approach.

The remainder of the paper is organized as follows; Next section discusses the building of railroads and their impacts in the Ottoman Empire considering the contributions of previous literature on the effects of railroads for different countries. Sections 3 and 4 undercover the data and empirical methodology applied. Section 5 canvasses the results and discusses, as Section 6 concludes. Appendix contains a description of instrumental variable.

\footnotetext{
5 Beyzatlar (2010) investigates the effect of railroads on the development of cities in one of the successor states to the Ottoman Empire, i.e., Turkey, in an econometric context using kilometres of railroads as a measure of railroad access. There are also some descriptive studies-such as Kolars \& Malin (1970) and Akgungor et al. $(2011,2012)$ - that study on the effect of railroads in the Ottoman Empire and Turkey, using historical data.

6 These countries are Turkey, Greece, Syria, Iraq, Lebanon, Israel, Palestine, Jordan, Yemen, and some parts of Albania, Macedonia, Kosovo, and Saudi Arabia.
} 


\section{Railroads and Economic Growth in the Ottoman Empire}

In the 1850s, the length of railroads was $620 \mathrm{~km}$ in Italy, as Spain had less than $100 \mathrm{~km}$ of railroad lines. Austria-Hungary, the UK, and the US had 1,357, 9,800, and 14,480 km of railroad lines, respectively (Kasaba 1993: 40-41; Quataert 1996: 804). By the 1860s, no railroad line operated in the Ottoman Empire. The existing road networks of the Ottoman Empire were in a poor condition (Kolars \& Malin 1970; Schoenberg 1977). ${ }^{7}$ There were many geographical, political and financial obstacles in building of railroads. Railroad construction began after 1855. As shown in Table 1, its railroad network grew to 8,334 km by 1914 (Schoenberg 1977; Eldem 1994: 103).

Table 1. The Railroad Lines in the Ottoman Empire (1856 and 1914)

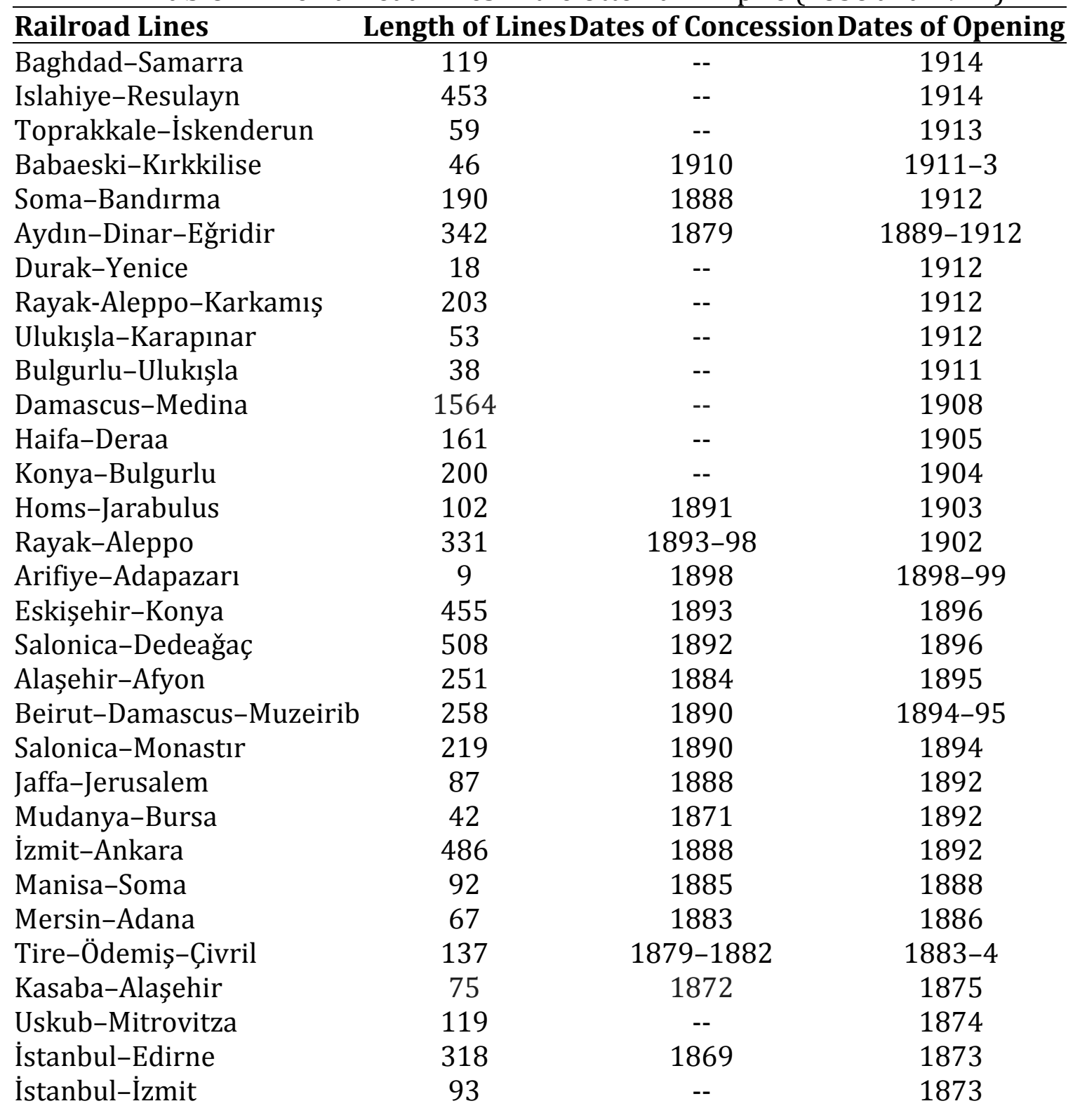

7 In 1914, there was 20,000 kilometres of highways, as the highways were not built well (Schoenberg, 1977; Engin 1993: 28-29; Quataert 1996: 818). 


\begin{tabular}{lccc} 
Edirne-Philipopoli-Belova & 243 & -- & 1872 \\
Salonica-Üsküb & 244 & -- & 1872 \\
Tirnova-Yanboli & 106 & -- & 1872 \\
Banialuka-Doberlin & 102 & -- & 1872 \\
Edirne-Dedeağaç & 149 & -- & 1872 \\
İzmir-Kasaba & 98 & 1863 & 1866 \\
Varna-Rustchuk & 220 & 1860 & 1866 \\
İzmir-Aydın & 130 & 1856 & 1866 \\
Chernovoda-Constantza & 66 & 1856 & 1860 \\
\hline
\end{tabular}

Notes: Table shows railroad lines that were within the border of the Ottoman Empire at the census dates. The information in are gathered from sources given in the data section. All of the railroad line names are given in the form in which they appear in these sources.

The Ottoman state primarily desired the construction of railroads to increase its political control over its territories. The poor roads hindered wars in remote locations and mobilization of troops to fight against rebellions. It did not have the funds to finance building of railroads and the contemporary technological knowledge for building railways. So, the foreign railroad firms of major European powers constructed and operated many railroad lines. Foreign firms built railroads to import raw materials cheaper and to extend their home countries' economic control (L. D. 1915; Kurmuş 1982: 48-49; Schoenberg 1977; Illich 2007: 91-93; Gülsoy 2010, p. 27; Geyikdağı 2011: 119-126).

French firms constructed railroads in Syria, Jaffa, and Jerusalem that had been the focus of French economic interests since eighteenth century (Shorrock 1970; Gülsoy 2010: 43-44). The railroad line between İzmir and Aydın was constructed by a British company, i.e., Smyrna-Aydın Railroad Company (British Parliamentary Paper 1896: 10; Issawi 1980: 183; Eldem 1994: 104). The UK imported figs and sultana raisins produced in Aydın through İzmir port (Karkar 1972: 65; Issawi 1982: 159). This line facilitated the transportation of agricultural products by shortening the travel time to only three hours. The UK imported raw materials and products, which was produced in Aydın, easier and cheaper than before (Karkar 1972: 65; Özyüksel 1988: 12).

The German firms constructed several railroad lines which were supposed to link the capital city of the Ottoman Empire (i.e., İstanbul) with Anatolia and Baghdad. Industrialization in Germany was positively related to demand for the cheap agricultural products and mineral resources of the Ottoman Empire after the 1880s. Germany would 
import them easily through the railroads ${ }^{8}$ (Dominian 1916; McMurray 2001: 40; McMeekin 2010: 36-37; Ortaylı 2010: 58). Railroad investments of German firms led to establishment of a threat to the British and French economic and political dominance in the Asia and the Ottoman Empire (Henderson 1948; Ökçün 1997: 15-56; McMurray 2001: 41; Illich 2007: 89; Gülsoy 2010: 43-44; Ortaylı 2010: 161-165).

Apart from these lines, though the financial problems, the Ottoman state constructed several lines itself, such as ones linking Damascus with Medina. ${ }^{9}$ They would bring the Arab provinces under the political control of the Ottoman state. The lines would connect the holy cities of the Islam to İstanbul (Gülsoy 1994: 45-46, 2010, p. 270; Hülagu 2010: 61-62, 148, 180-1).

Sometimes, foreign railroad firms were required to change locations of tracks by the Ottoman state to due to political and strategic reasons (Schoenberg 1977). For instance, the line linking Ankara with Aleppo did not pass through rich places even if a German firm had planned to construct it in places that were not poor in agricultural resources (i.e., the Mediterranean coast). The Ottoman state wanted the lines to be built in places that were located further away from the coast which would be under attack if a war broke out (Schoenberg 1977; Quataert 1996: 806). Moreover, foreign firms built unnecessary railroad lines, to get more money due to payments of the Ottoman state to them per kilometre of railroad line that was put into operation, i.e., kilometric guarantee system. So, railroad lines did not exactly pass through different places, which were not in their construction plans (Schoenberg 1977; Issawi 1982: 60).

In the previous literature, railroads are found to be positively related to trade, production, and population in different countries. This impact is attributed to decreasing transportation costs. Because of the fall in transportation costs, consumers could buy goods in the cheapest places, as producers could sell goods in the most expensive ones. By creating new marketing opportunities for goods, railroads are associated with higher production in the respective places (Atack et al. 2010; Donaldson, 2010; Atack \& Margo, 2011; Kotavaara et al. 2011; Schwartz et al. 2011; Koopmans et al. 2012; Berger \& Enflo 2015; Wang \& Wu 2015; Jedwab \& Moradi 2016). Increasing trade and agricultural production is positively correlated with employment opportunities. This attracted an

8 Additionally, since railroad companies of Germany had rights to exploit any mineral resources - such as oil-found within $20 \mathrm{~km}$ of tracks, German industry would gain access to mineral resources of the Ottoman Empire via railroad investments (Karkar 1972: 87, Engin 1993: 28-29; Owen 2002: 196-197).

9 The railroad lines were named as the Hejaz railway. 
inflow of people seeking jobs. Higher income level also created in increasing fertility rates. Resultantly, the railroad access was positively associated with population in these areas (Hornung 2015).

Quataert (1996: 814, 2005: 126) argues lower transportation costs thanks to railroads in the Ottoman Empire, leading to a gradual increase of trade in places that had gained access to railroads. For instance, as goods were easily carried from Anatolia to ports by railroads, exports through the ports increased (Karkar 1972: 65, 82; Quataert 1977; Quataert 1996: 814). As shown in Figure 1, the number of rail passengers in the Ottoman Empire gradually increased to 14 million in 1913, which could imply higher mobility thanks to railroads. Railroads were positively correlated with agricultural production in connected places through expanding available markets for agricultural goods (Hanioğlu 2008: 137). Eldem (1994: 94) shows 114 \% increase of agricultural production in places that had gained access to railroads between 1889 and 1911, as compared to $63 \%$ increase in agricultural production of the other places. Finally, because of increasing trade, agricultural production, safety, and employment opportunities —in such areas as Damascus, Maan, Amman, Der'a, İzmir, Ușak, and Konya-, gaining access to the railroads was associated with higher population (British Parliamentary Paper 1896: 10; Quataert 1996: 813-814; Gülsoy 1994: 245-256, 2010 : 181-182, 270; Hülagu 2010: 14-45).

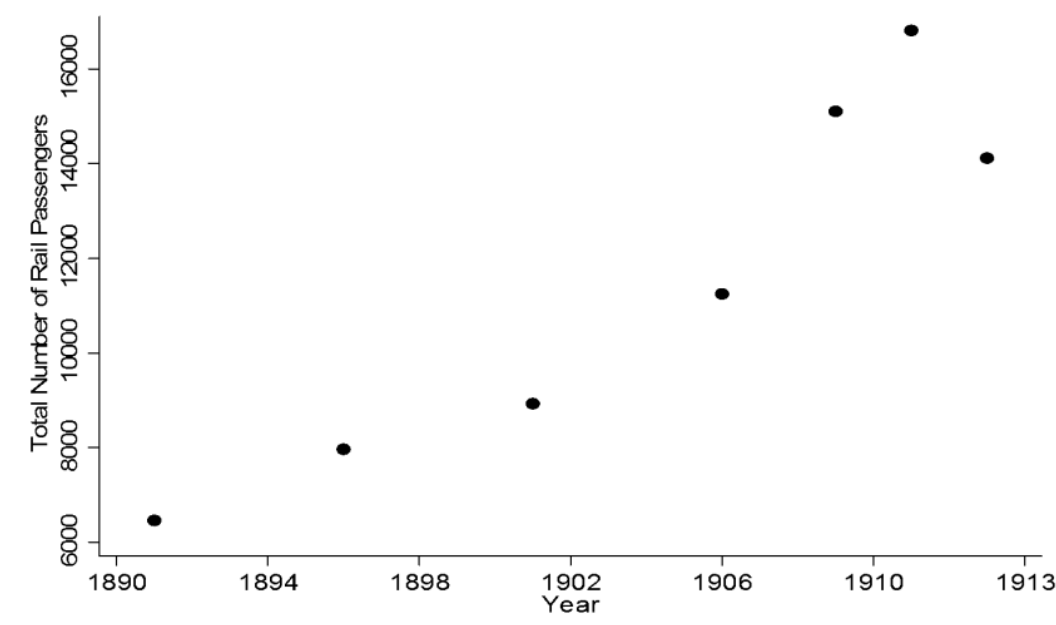

Figure 1. Total number of rail passengers in the Ottoman Empire (1891-1913) Source: The data come from Eldem (1994: 102). Note: All values are expressed in million persons. 


\section{Data}

To examine whether railroad access induced economic growth in the Ottoman Empire, we use population of 628 judicial districts as a proxy. The data come from 1881/82-9310 and 1914 censuses, which have been made available by Karpat (1985: 122-150, 167190). ${ }^{11}$ Karpat (1985) includes detailed information on the other censuses which were conducted in different years (e.g., 1831, 1844, 1866/73, 1877/78, and 1906/07 censuses). The female population was neglected in some of these censuses. In addition, several censuses did not provide detailed data on population of judicial districts. Finally, after administrative reforms of 1864, borders of administrative units in the Ottoman Empire could have changed (Sezen 2006).

As a regressor of interest, we use the shortest distance between each judicial district centre and railroad line at the census dates. A possible challenge is that the layout of railroad networks in the Ottoman Empire is not available in digital format. Several sources ${ }^{12}$ give detailed information on the location of tracks and railroad stations, building and opening dates of the lines. We construct a detailed map of the railroad lines in the Ottoman Empire that shows the location of railroad lines by both place and year.

We also use several control variables to effect population level. These are the presence of the natural disasters and mines in the judicial districts. The data for natural disasters come from Evengelatou-Notora (2001: 99-121), Vogt (2001: 11-71), and Erler (2010: 102-131). The natural disasters were caused by rainfall shortages, drought, floods, and earthquakes. The information on mines, such as coal, cooper, are extracted

\footnotetext{
10 The 1881/82-93 was conducted since 1881 and submitted to the Sultan in 1893 (Karpat 1985, pp. 30 36). One concern with the censuses is the absence of clear information about the finishing time of the 1881/82-93 census. It seems that population figures of the 1881/82-93 census can be used as a good proxy for total number of people which lived in the judicial districts in 1893, as suggested by Dölek (2007: 16) who compares the population figures of the 1881/82-93 census with the population figures in other reliable sources which provided detailed information on population of provinces. Karpat (1985: 33) argues that the censuses of most of territories in the Ottoman Empire were finished in 1889. We reestimate regressions after considering 1889, as the completion year of the 1881/82-93 census. This exercise does not change the results much. There were not many lines that were built between 1881 and 1893.

${ }^{11}$ Several factors - such as undercounting of people living in several places due to religious reasonscause measurement error in population data. Also, people living in a distant location could be undercounted (Karpat 1985: 10, 34). This measurement error may lead to biased OLS estimate. Finally, as there is no available information for locations of several judicial districts in the historical maps and documents, the paper has missing observations, which is about $8 \%$.

${ }^{12}$ Some of them are Kolars \& Malin (1970), Karkar (1972), Schoenberg (1977), Eldem (1994), Geyikdağı (2011), and Özyüksel (2014).
} 
from Su (1939), Eldem (1994: 41-57), Quataert (1996: 55-64), Yorulmaz (1998), Quataert (2006: 1-52), and Geyikdağı (2011: 119-126).

As instrument for the railroad access in 2SLS, we use the shortest distance between each judicial district centre and trade routes. There is no available map of trade routes in digital format. Several sources ${ }^{13}$ provide detailed information on start and end points of the trade routes. Owen (2002: 48) contains a map of network for trade routes connecting various locations. We create a map of the routes, which identifies various links among places along the trade routes in the Ottoman Empire.

Summary statistics for the variables in the sample are presented in Table 2. The average population of a judicial district was 35,728 . On average, a judicial district was $176 \mathrm{~km}$ away from a railroad line. This shows that railroad networks in the Ottoman Empire were not that dense. In $8 \%$ of judicial districts, natural disasters were seen between 1800s and 1850s. There was at least one operating mine in $18 \%$ of judicial districts over the sample period. On average, a judicial district was $89 \mathrm{~km}$ away from the trade routes.

Table 2. Descriptive Statistics

\begin{tabular}{lccc}
\hline Variable & N. of obs. & Mean & Std. Dev. \\
\hline Population & 738 & 35,729 & 32,993 \\
Distance to railroad lines & 738 & 176 & 202 \\
Presence of natural disasters & 738 & 0.083 & 0.275 \\
Presence of mines & 738 & 0.182 & 0.386 \\
Distance to trade routes & 738 & 89 & 87 \\
\hline
\end{tabular}

Notes: N. of obs. denotes the total number of judicial district-year observations. Std. Dev. displays standard deviations of variables in the sample.

\section{Methodology}

To test the effects of railroads on population, the paper runs the following regression:

$$
\ln \left(P_{i c p t}\right)=\beta_{0}+\beta_{1} \ln \left(R_{i c p t}\right)+\beta_{2} D_{i c p} \times \gamma_{t}+\beta_{3} M_{i c p t}+\rho_{p}+u_{i c p t}
$$

where $i, c, p$, and $t$ index judicial district, county, province, and year, respectively. $\ln \left(P_{i c p t}\right)$ is the natural logarithm of population for judicial district $i$, located in county $c$ of province $p$, in year $t^{14}$

$\ln \left(R_{i c p t}\right)$ is the natural logarithm of the distance between nearest railroad line and each judicial district, in year $t$. To control for initial conditions in a judicial district, we

\footnotetext{
13 Some of them are Karkar (1972), Quataert (1995), and Owen (2002).

${ }^{14}$ In this paper, the administrative division of the Ottoman Empire is based on Karpat (1985, p. 190) to maintain consistency in province borders. In Karpat (1985), the Ottoman Empire was divided to the 32 largest administrative units. These units were special districts (e.g., İzmit and Çatalca special districts), provinces (e.g., Aydın province), a county (i.e., Zor), and capital city of the Empire (i.e., İstanbul). In this paper, special district, Zor county, and the capital city are considered as provinces.
} 
use $D_{\text {icp. }} D_{\text {icp }}$ equals 1 if natural disasters were seen in judicial district $i$ of county $c$, located in province $p$, between 1800s and 1850s, and zero otherwise. $M_{\text {icpt }}$ is a dummy variable which equals 1 if there was at least one operating mine-such as coal, gold, and copper mine-in judicial district $i$ of county $c$, located in province $p$, in year $t$, and zero otherwise. Historical literature argues that there was an increase in population and production in several places-such as Balya judicial district in Balıkesir-after coal mines had been operating in the 1900s in the respective locations ( $\mathrm{Su}$ 1939: 6-12). Additionally, the regression includes the interaction of $D_{i c p}$ with year dummies $\left(y_{t}\right)$ which control for the time varying effects of different initial conditions in each judicial district. $p_{p}$ are province fixed effects which account for time-invariant characteristics at province level (e.g. presence of mountains, rivers, lakes, and geographic size). ${ }^{15}$ Lastly, $u_{\text {icpt }}$ is the error term while $\beta_{1}$ is coefficient of interest.

Being closer to a railroad line was positively correlated with economic growth through higher production and trade which attracted an inflow of workers and their families as well as fertility increase, implying a negative $\beta_{1}$. A positive coefficient estimate of $\beta_{1}$ supports that being closer to a railroad line led to a decrease in production and trade through higher imports which resulted in hampering of domestic industry, and consequently population went down due to increasing migration and lower fertility rate.

\section{Results}

\subsection{Basic results}

The findings are presented in Table 3. OLS estimate for the effect of railroads in column (1) is statistically significant at $1 \%$. The point estimate reveals that $1 \%$ decrease in the distance from a judicial district to the nearest railroad line leads to an increase in population of the respective judicial district by $0.07 \%$, on average. This finding means the positive impact of railroad access on population in the judicial districts of the Ottoman Empire through higher economic growth.

\footnotetext{
15 Due to small sample size issues, we do not use judicial district dummies to control for time-invariant unobserved judicial district characteristics such as presence of mountains in judicial districts. Furthermore, this is a similar methodology applied by Banerjee et al. (2012) who examine the effect of railroads on economic and demographic outcomes in China.
} 
Table 3. The impact of railroads in the Ottoman Empire (1893 and 1914)

Dependent variables: In(Population)

\begin{tabular}{lccc}
\hline & OLS & 2SLS & LIML \\
\hline & 1 & 2 & 3 \\
\hline In(Distance to railroad lines) & $-0.071^{* * *}$ & $-0.281^{* *}$ & $-0.281^{* *}$ \\
& $(0.022)$ & $(0.129)$ & $(0.129)$ \\
Presence of natural disasters & 0.287 & 0.161 & 0.161 \\
& $(0.181)$ & $(0.199)$ & $(0.198)$ \\
Presence of mines & $0.396^{* * *}$ & $0.347^{* * *}$ & $0.347^{* * *}$ \\
& $(0.080)$ & $(0.078)$ & $(0.078)$ \\
Constant & $9.706^{* * *}$ & $10.175^{* * *}$ & $10.175^{* * *}$ \\
& $(0.056)$ & $(0.300)$ & $(0.300)$ \\
\hline N. of obs. & 738 & 738 & 738 \\
$\mathrm{R}^{2}$ & 0.37 & 0.28 & 0.28 \\
First-Stage F statistic & -- & 12.05 & 12.05 \\
\hline
\end{tabular}

\section{Dependent Variable In(Distance to Railroad Lines)}

$\begin{array}{lcc}\ln (\text { Distance to trade routes) } & 0.297^{* * *} & 0.297^{* * *} \\ & (0.073) & (0.072) \\ \mathrm{R}^{2} & 0.62 & 0.62\end{array}$

Notes: Columns (1) reports the OLS estimates for equation (1). In column (2), regression is estimated by 2SLS. In column (3), regression is estimated by LIML. The dependent variable in columns (1)-(3) is the natural logarithm of the population in a judicial district in year $t$. The dependent variable in the first-stage regressions is the natural logarithm of distance to railroad lines in year $t$. Results for the control variables are not reported in the first-stage results. Heteroskedasticity-robust standard errors corrected for clustering at the province level are reported in parentheses. ${ }^{* * *}$ and ${ }^{* *}$ denote statistically significantly different from zero at $1 \%$ and $5 \%$ levels, respectively. N. of obs. is number of observation. First-Stage $\mathrm{F}$ statistic implies F statistic on the excluded instrument in the first stage regression. Last, distance to trade routes is instrumental variable.

In column (2), we address the possibility that placement of railroad lines could be endogenous to population growth (i.e. reverse causality), leading to bias in the OLS estimate for the impact of railroads. This is because several railroad lines were allocated to commercially important places (i.e., İzmir and Aydin) (Kolars \& Malin 1970; Karkar 1972: 65, 79). The Ottoman state wanted to be built some railroad lines in unpopulated places-such as Bandirma and Balıkesir-, that were affected by famines. The railroad lines would decrease food shortages and prevent future famines in the respective places (Quataert 1996: 789; Erler 2010: 304-312). Furthermore, since the Ottoman state aimed to extend its political control over distant areas via railroads, several railroad lines were assigned to politically important places where not many people lived. Foreign railroad firms had been paid for each kilometre of lines put into operation or the Ottoman state provided financial aid. For this reason, they agreed to build and operate lines in politically important places for the Ottoman state despite the low population 
(Karkar 1972: 75, 111; Quataert 1977; Schoenberg 1977; Issawi 1982: 60). Finally, due to measurement error in the population and railroad data, the OLS could underestimate the impact of railroads in absolute value in case of measurement error. ${ }^{16}$

We construct an instrumental variable for railroads based on trade routes (i.e., the natural logarithm of the shortest distance between each judicial district and the trade routes). ${ }^{17}$ Column (2) reports statistically significant 2SLS estimate for the effect of railroads at $5 \%$. The point estimate shows that $1 \%$ fall of the distance from a judicial district to the nearest railroad line was correlated with an increase in population of the respective judicial district by $0.28 \%$, on average. The 2SLS estimate is larger than OLS coefficient in magnitude, which suggests that the OLS estimate is biased downward. The second stage result is presented in column (3) of Table 2. The F-statistic is larger than 10 , implying that the instrument is not weak.

Although first-stage F-statistic is above the rule of thumb (10), it passes this threshold by a small margin. As it is known, the results of 2SLS are biased under weak instruments. In order to examine this suspicion, the Limited Information Maximum Likelihood (LIML) estimation is suggested, since this technique provides less biased estimators than those of 2SLS. Therefore, we also provide LIML results in the last column of Table 2. As Angrist \& Pischke (2009) underline, estimates and standard errors with 2SLS and LIML should be compared and if the results are almost same there is not much reason to worry. The findings in column (3) show that the coefficient and standard error provided by LIML are not so different than the one of the 2SLS.

\subsection{Robustness checks}

Hornung (2015) uses urban population to examine the impact of railroads on population growth in Prussia. To the best of our knowledge, there was an absence of definition of urban and rural areas in available resources on the Ottoman Empire. We estimate regressions without places whose population was smaller than the population mean (i.e., 35,728). The OLS and 2SLS estimates are presented in column (1) and (2) of Table 4 , respectively. This does not make much difference in the results. This supports that railroads induced economic growth due to increasing fertility rates and migration to urban centres that were connected by railroads, as a society needed significant surplus to support all people that were not farming.

\footnotetext{
16 See Hanedar (2013) for detailed discussion on this issue.

17 See appendix for detailed discussion on the instrumental variable.
} 
Table 4. Robustness Checks

\begin{tabular}{lcccc}
\hline \multicolumn{5}{c}{ Dependent variable: $\ln ($ Population) } \\
\hline & 1 & 2 & 3 & 4 \\
\hline In(Distance to railroad lines) & $-0.082^{* * *}$ & $-0.284^{* *}$ & $-0.060^{* *}$ & $-0.224^{*}$ \\
& $(0.028)$ & $(0.103)$ & $(0.022)$ & $(0.118)$ \\
Presence of natural disasters & 0.149 & -0.015 & 0.289 & 0.192 \\
& $(0.141)$ & $(0.163)$ & $(0.182)$ & $(0.197)$ \\
Presence of mines & $0.276^{* * *}$ & $0.239^{* * *}$ & $0.372^{* * *}$ & $0.334^{* * *}$ \\
& $(0.062)$ & $(0.059)$ & $(0.078)$ & $(0.077)$ \\
Constant & $12.645^{* * *}$ & $13.087^{* * *}$ & $9.698^{* * *}$ & $10.064^{* * *}$ \\
& $(0.110)$ & $(0.266)$ & $(0.058)$ & $(0.276)$ \\
\hline N. of obs. & 263 & 263 & 715 & 715 \\
$\mathrm{R}^{2}$ & 0.38 & 0.10 & 0.32 & 0.26 \\
$\mathrm{~F}$ & -- & 7.42 & -- & 10.90 \\
\hline
\end{tabular}

Notes: Heteroskedasticity-robust standard errors corrected for clustering at the province level are reported in parentheses. ${ }^{* * *}, * *$, and $*$ denote statistically significantly different from zero at $1 \%, 5 \%$, and $10 \%$ levels, respectively. N. of obs. is number of observation. At the last row, F statistics on the excluded instrument in the first stage regression are reported. Last, distance to trade routes is instrumental variable.

Female population in several places such as Basra province could have been neglected in the 1881/82-93 census (Karpat 1985: 151). To address this issue, columns (3) and (4) report the OLS and 2SLS estimates after omitting judicial districts in these places from the analysis which leads to a decrease in the number of observations from 738 to 715 . The results are not much sensitive to exclusion of these provinces.

\subsection{Discussions}

Our empirical results suggest that access to railroads had induced economic growth, which was related to higher population figure in the respective judicial districts. The findings are parallel to one strand of the historical literature, indicating higher international and interregional trade due to lower transportation costs (such as British Parliamentary Paper (1896: 10), Karkar (1972: 65, 82), Quataert (1977; 1996: 810-814; 2005: 126), and Eldem (1994: 94)). Higher trade level was correlated with increasing agricultural production in places that had gained access to railroads, leading to higher employment opportunities. This attracted an inflow of people looking for employment and jobs and a birth surplus in the affected areas because of increasing feeding possibilities.

The findings from 2SLS and LIML regression could imply that railroad lines could be located in a place regardless its economic importance or population. This is because selection of a place for railroad construction in the Ottoman Empire was correlated with strategic, religious, and political rather than economic reasons. It could be also argued that measurement error is another concern. 


\section{Conclusion}

Railroads are expected to have a strong effect on economic growth in the respective places through increasing trade and production, which is attributed to the decreasing transportation costs. To identify the effects of railroads on economic growth, we examine that being closer to a railroad line was related to higher population of a judicial district in the Ottoman Empire. Higher production level could be associated with a birth and migration surplus in the affected areas. We contribute to the previous literature, as the empirical findings pointing out the role of railroads to induce economic growth in a dissolving country, where road networks are poor. Railroads were correlated with higher factor mobility and population level in the affected areas, although political factors play an important role on their construction.

The paper could be refined if a dataset on economic outcomes were available. There is a need to further study on the decisions about the placement of railroad lines, as the instrument could fail to satisfy the exclusion restriction. The absence of a dataset on migration at the judicial district level and border changes would lead to future work. Circassian immigrants from Russia were placed by the Ottoman state in areas that were close to the railroad lines. In addition, railroads were correlated with an increase in migration from interior regions to ports and abroad, which could lead to lower economic activity (Quataert 1996: 791-795). However, there is limited information on the borders of administrative units in the Ottoman Empire. Only a few kinds of economic and financial data from the Ottoman Empire have yet been gathered.

\section{Appendix: Instrumental variable approach}

Duranton and Turner (2007) and Baum-Snow (2007) provide evidence that new roads are likely to be built in places where initial roads are located. This is because initial roads are located in suitable places that construction of new roads is easy and inexpensive. Similarly, Quataert (1996: 820-821) argues that several railroad linessuch as line between İzmir and Aydın, and the Anatolian railway were built in places along the trade routes.

The exclusion restriction requires that the instrumental variable in this study does not have an effect on population via any other channel such as physical geography. There are three potential concerns with the exclusion restriction.

The first potential concern is that commercial, production, and financial activities were concentrated in places along the trade routes. For instance, Bursa was an 
important cotton cloth manufacturing place as İstanbul and İzmir were the most important ports in the Ottoman Empire (Schoenberg 1977; Owen 2002: 45-50).

The instrumental variable is not strongly related to population via this channel. The trade routes-such as the route connecting Erzurum with Trabzon-declined in importance for the Ottoman economy in the nineteenth century due to several reasons. First, roads were not repaired due to financial difficulties. Second, wars and rebellions led to the presence of security problems in places along the trade routes. Also, several trade routes were disrupted by wars. Third, there were heavier taxes or corruption in locations along the trade routes, as prices of goods was high, which resulted in decreasing of trade. Last, other routes—such as the Suez Canal-bypassed the trade routes of the Ottoman Empire (Issawi 1970; Karkar 1972: 59-61; Engin 1993: 27-29; Quataert 1996: 768).

The historical literature argues that trade through ports in the Ottoman Empire were not high in nineteenth century. ${ }^{18}$ The Ottoman state had limited funds for maintenance and improvement of the ports. Wars were negatively correlated with trade through the ports. Opening of new roads and ports in border countries reduced trade through the ports of the Ottoman Empire. For instance, railroads in Georgian coast hampered trade through port in Trabzon (Schoenberg 1977; Eldem 1994: 95-96; Quataert 1996: 767-768).

The second potential concern is the poor condition of the existing road networks of the Ottoman Empire. The trade routes were still in use for carrying goods and people by camel caravans over the sample period (Karkar 1972: 59-61; Schoenberg 1977; Engin 1993: 28-29; Quataert 1996: 817-819). There is no reliable data on road networks of the Ottoman Empire that were used over the sample period. The regression includes many control variables, including time varying measure of operating mines, along with province and year fixed effects which can capture omitted road network.

The third potential concern is that places along the trade routes could be attractive destinations to live. As a result, the 2SLS estimate for the impacts of railroads could overestimate the relationship between railroads and population.

The column (1) of Table A1 provides the reduced form results. As expected, distance to trade routes is negatively and statistically significantly related with

18 This is in line with arguments and findings of Acemoglu et al. (2002). Acemoglu et al. (2002) show that trade through Mediterranean ports-such as ports of the Ottoman Empire-were not increasing as much as trade through Atlantic ports during the nineteenth century. 
population. As we use distance to trade routes as an instrument for distance to railroad lines, the effect of distance to trade routes on population works through the distance to railroad lines. In order to test this, we add both the distance to railroad lines and the distance to trade routes simultaneously. Results in column (2) show that while the effect of distance to railroad lines is negative and statistically significant, the effect of distance to trade routes loses its significance. This result suggests that distance to trade routes had no direct effect on population when distance to railroad lines is added into the regression. Empirical findings in columns (1) and (2) show that distance to trade routes effects population through the distance to railroad lines. This implies that distance to trade routes can be used as an instrument for distance to railroad lines.

Table A1. Reduced Form Results

\begin{tabular}{lcc}
\hline \multicolumn{3}{c}{ Dependent variable: $\ln ($ Population) } \\
\hline $\ln$ (Distance to railroad lines) & -- & 2 \\
& & $-0.054^{* *}$ \\
$\ln$ (Distance to trade routes) & $-0.083^{* *}$ & -0.067 \\
& $(0.037)$ & $(0.040)$ \\
Presence of natural disasters & 0.295 & 0.269 \\
& $(0.185)$ & $(0.182)$ \\
Presence of mines & $0.391^{* * *}$ & $0.382^{* * *}$ \\
& $(0.085)$ & $(0.081)$ \\
Constant & $9.778^{* * *}$ & $9.855^{* * *}$ \\
& $(0.102)$ & $(0.094)$ \\
\hline N. of obs. & 738 & 738 \\
$\mathrm{R}^{2}$ & 0.37 & 0.38 \\
\hline
\end{tabular}

Notes: Columns (1) and (2) report the OLS estimates. The dependent variable is the natural logarithm of the population in a judicial district in year $t .^{* * *}$ and ${ }^{* *}$ denote statistically significantly different from zero at $1 \%$ and $5 \%$ levels, respectively. N. of obs. is number of observation.

\section{References}

Acemoglu, D. Johnson, S., Robinson, J. 2002. The rise of Europe: Atlantic trade, institutional change and economic growth.NBER working papers 9378, National Bureau of Economic Research.

Akgungor, S., Aldemir, C., Kustepeli, Y., Gulcan, Y., Tecim, V. 2011. The Effect of railway expansion on population in Turkey, 1856-2000. Journal of Interdisciplinary History 42, 135-157.

Akgungor, S., Aldemir, C., Kustepeli, Y., Gulcan, Y., Tecim, V. 2012. Türkiye'de demiryollar1 ve karayollarının ekonomik ve sosyal etkileri: 1856-2008 dönemi için bir inceleme. İzmir, Dokuz Eylül Üniversitesi yayınları. 
Angrist, J. D. \& Pischke, J. S. 2009. Mostly harmless econometrics: An empiricists' companion. Princeton University Press, Princeton, New Jersey.

Ansar, A., Flyvbjerg, B., Budzier, A., Lunn, D. 2016. Does infrastructure investment lead to economic growth or economic fragility? Evidence from China. Oxford Review of Economic Policy 32, 360-390.

Atack, J. \& Margo, R. 2011. The impact of access to rail transportation on agricultural improvement: The American Midwest as a test case, 1850-1860. The Journal of Transport and Land Use 4, 5-18.

Atack, J., Bateman, F., Haines, M., Margo, R. A. 2010. Did railroads induce or follow economic growth? Urbanization and population growth in the American Midwest, 185060. Social Science History 34, 171-197

Atack, J., Haines, M., Margo, R. A. 2011. Railroads and the rise of the factory: Evidence for the United States, 1850-1870. Rhode, P., Rosenbloom, J., Weiman, D. (Eds), Economic evolution and revolutions in historical time, Stanford University Press, Palo Alto. 162179.

Banerjee, A., Duflo, E., Qian, N. 2012. On the road: Access to transportation infrastructure and economic growth in China. NBER working papers 17897, National Bureau of Economic Research.

Banerjee. A. V., Duflo, E., Qian, N. 2012. On the road: Access to transportation infrastructure and economic growth in China. NBER working papers 17897, National Bureau of Economic Research.

Baum-Snow, N. 2007. Did highways cause suburbanization?. The Quarterly Journal of Economics, 122, 775-805.

Berger, T. \& Enflo, K. 2015. Locomotives of local growth: The short- and long-term impact of railroads in Sweden. Journal of Urban Economics (Forthcoming).

Beyzatlar, M. A. 2010. The impact of railway infrastructure on economic growth and population in Turkey. MA Thesis. Dokuz Eylül University, İzmir.

British Parliamentary Paper, 1896. Report by major law on railways in Asiatic Turkey. 19th Century House of Commons paper UK National Archives. 8019. 1-21.

Caruana-Galizia, P. \& Martí-Henneberg, J. 2013. European regional railways and real income, 1870-1910: a preliminary report. Scandinavian Economic History Review 61, 167-196 
Dölek, D. 2007. Change and continuity in the Sivas province, 1908-1918. MA Thesis. Middle East Technical University, Ankara.

Dominian, L. 1916. The geographical foundation of Turkey's world relation. Journal of the American Oriental Society 36, 168-180.

Donaldson, D. \& Hornbeck, R. 2017. Railroads and American Economic Growth: A “Market Access" approach. The Quarterly Journal of Economics (Forthcoming).

Donaldson, D. 2010. Railroads and the Raj: Estimating the economic impact of transportation infrastructure. NBER working papers 16487, National Bureau of Economic Research.

Duranton, G. \& Turner, M. A. 2007. Urban growth and transportation. University of Toronto department of economics working papers 307, University of Toronto.

Eldem, V. 1994. Osmanlı İmparatorluğu'nun iktisadi şartları hakkında bir tetkik. Türk Tarih Kurumu yayınları, İstanbul.

Engin, V. 1993. Rumeli demiryolları. Eren yayıncılık, İstanbul.

Erler, M. Y. 2010. Osmanlı Devleti'nde kuraklık ve kitlık olayları (1800-1880). Libra yayınevi, İstanbul.

Evengelatou-Notora, F. 2001. İkincil önemdeki Yunanca kaynaklarda doğal afetler (14.19.Yuzyıllar). Zachariadou, E. (Ed), Osmanlı İmparatorlugu'nda doğal afetler. Tarih Vakfı Yurt yayınları, İstanbul. 121-133.

Fogel R. 1964. Railroads and American Economic Growth: Essays in econometric history. The Johns Hopkins University Press, Baltimore.

Geyikdağı, V.N. 2011. Foreign investment in the Ottoman Empire: International trade and relations 1854-1914. Tauris Academic Studies, London.

Gülsoy, U. 1994. Hicaz demiryolu. Eren yayınları, İstanbul.

Gülsoy, U. 2010. Kutsal proje - Ortadoğu'da Osmanlı demiryolları. Timaş yayınları, İstanbul.

Haines, M. \& Margo, R. A. 2008. Railroads and local development: The United States in the 1850s. J. Rosenbloom (Ed), Quantitative economic history: The Good of counting. Routledge, London, 78-99.

Hanedar, A 0. 2013. Three essays on the economy of the late Ottoman Empire. Ph.D Thesis. University of Essex, Colchester.

Hanioğlu, M. S. 2008. A brief history of the Late Ottoman Empire. Princeton University press, Princeton. 
Henderson, W.O. 1948. German economic penetration in the Middle East, 1870-1914. The Economic History Review 18. 54-64.

Hornung, E. 2015. Railroads and growth in Prussia. Journal of the European Economic Association 13.699-736.

Hülagü, M. M. 2010. The Hejaz railway: the construction of a new hope. Bluedome press, New York.

Illich, N. S. 2007. German imperialism in the Ottoman Empire: A comparative study. Unpublished PhD Thesis, Texas A\&M University, Texas.

Issawi, C. 1980. The Economic history of Turkey, 1800-1914. University of Chicago press, London.

Issawi, C. 1982. An economic history of the Middle East and North. Columbia University press, London.

Jedwab, R. \& Moradi, A. 2016. The permanent effects of transportation revolutions in poor countries: evidence from Africa. Review of Economics and Statistics 98, 268-284.

Karkar, Y. N. 1972. Railway Development in the Ottoman Empire, 1856-1914. Vantage Press, New York.

Karpat, K. H. 1985. Ottoman Population 1830-1914: Demographic and Social Characteristics. The University of Wisconsin Press, Wisconsin.

Kasaba, R. 1993. Osmanlı İmparatorluğu ve Dünya Ekonomisi Ondokuzuncu Yüzyıl. Belge Yayınları, İstanbul.

Kolars, J. \& Malin, H. J. 1970. Population and accessibility: An analysis of Turkish railroads. The Geographical Review 60. 229-246.

Koopmans, C., Rietveld, P., Huijg, A. 2012. An accessibility approach to railways and municipal population growth, 1840-1930. Journal of Transport Geography 25. 98-104.

Kotavaara, O., Antikainen, H., Rusanen, J. 2011. Urbanization and transportation in Finland, 1880-1970. Journal of Interdisciplinary History. 89-109.

Kurmuş, 0. 1982. Emperyalizmin Türkiye'ye girişi. Savaş Yayınları, Ankara.

L. D. 1915. Railroads in Turkey. Bulletin of the American Geographical Society 47. 934940.

McMeekin, S. 2010. The Berlin-Baghdad Express: The Ottoman Empire and Germany's bid for world power, 1898-1918. Allen Lane, London.

McMurray, J. S. 2001. Distant ties: Germany, the Ottoman Empire, and the construction of the Baghdad railway. Praeger, Westport, Conn. 
Nathan N. 2009. The importance of history for economic development. Annual Review of Economics 1.65-92.

Ökçün, G. 1997. İktisat tarihi yazıları. Sermaye Piyasası kurulu, Ankara.

Ortaylı, I. 2010. Osmanlı İmparatorluğu'nda Alman nüfuzu. Timaş yayınları, İstanbul.

Owen, R. 2002. The Middle East in the world economy, 1800-1914. Tauris and Co Ltd. London.

Özyüksel, M. 1988. Anadolu ve Bağdat demiryolları. Arba yayınları, İstanbul.

Özyüksel, M. 2014. The Hejaz railway and the Ottoman Empire: Modernity, industrialisation and Ottoman decline. I. B. Tauris and Co Ltd. London.

Quataert, D. 1977. Limited revolution: The impact of the Anatolian railway on Turkish transportation and the provisioning of Istanbul, 1890-1908. The Business History Review 51. 139-160.

Quataert, D. 1996. The age of reforms, 1812-1914. Inalcık, H. and Quataert, D. (Eds), An economic and social history of the Ottoman Empire, 1300-1914. Cambridge University press, Cambridge. 749-943.

Schoenberg, P. E. 1977. The evolution of transport in Turkey (Eastern Thrace and Asia Minor) under Ottoman rule, 1856-1918. Middle Eastern Studies 13. 359-372.

Schwartz, R. M., Gregory, I., Thevenin, T. 2011. Spatial history: Railways, uneven development, and population change in France and Great Britain, 1850-1914. Journal of Interdisciplinary History 42. 53-88.

Sezen, T. 2006. Osmanlı yer adları. T.C. Başbakanlık Devlet Arşivleri Genel Müdürlügü̈, Ankara.

Shorrock, W. I. 1970. The origin of the French mandate in Syria and Lebanon: The railroad question,1901-1914. International Journal of Middle East Studies 1.133-153.

Su, K. 1939. Balıkesir madenleri. Resimli Ay matbaası, İstanbul.

Vogt, J. 2001. Osmanlı topraklarında tarih boyunca depremsellik: Batılı kaynaklardan ve tanıkların ifadelerinden Örnekler. Zachariadou, E. (Ed), Osmanlı İmparatorluğu'nda doğal afetler, Tarih Vakfı Yurt yayınları, İstanbul. 13-59.

Von Pressel, W. 1966. Railway projects in Turkey, 1872-1900. Issawi, C. (Ed.), The Economic History of the Middle East 1800-1911. University of Chicago press, Chicago. 90-94.

Wang, Y., \& Wu, B. 2015. Railways and the local Economy: Evidence from Qingzang railway. Economic Development and Cultural Change, 63, 551-588. 
Yorulmaz, S. 1998. Türkiye'de Kömürün Keşfi ve Kömür İşletme İmtiyazları (18291937). Paper presented at the 11th Turkish Coal Congress, 10-12 June, Bartın. 